\title{
Modeling Some Physico-Mechanical Properties of Tomato
}

\author{
Mohammad Ali Ghazavi ${ }^{1}$, Rahim Karami ${ }^{2} \&$ Mahmood Mahmoodi ${ }^{2}$ \\ ${ }^{1}$ Islamic Azad University, Khorasgan Branch, Isfahan, Iran \\ ${ }^{2}$ Department of Agricultural Machinery Engineering, Faculty of Agriculture, University of Shahrekord, \\ Shahrekord, Iran \\ Correspondence: Mahmood Mahmoodi, Department of Agricultural Machinery Engineering, Faculty of \\ Agriculture, University of Shahrekord, Shahrekord, Iran. Tel: 98-912-831-4857. E-mail: \\ m.mahmoodi5@gmail.com
}

Received: July 16, 2012 Accepted: September 10, 2012 Online Published: December 13, 2012

doi:10.5539/jas.v5n1p210 URL: http://dx.doi.org/10.5539/jas.v5n1p210

\begin{abstract}
The purpose of this study was measuring some physico-mechanical properties of tomato varieties ('Kariz', 'Darbigo', 'Falkato', 'Newton', and 'Shaqayeq') for three ripeness levels as a completely random factorial test; furthermore estimating the mass of the samples, using some new mathematical models, and volume, using image processing techniques. It was signified that the 'Kariz' had the most volume, total soluble solids, and sphericity among the varieties and was suitable for paste industry, furthermore due to its highest elasticity modulus $(E=0.167 \mathrm{Mpa}$ ), had the most resilient. After comparing the relations of estimating the mass, the regression model using three dimensions (length, width, and thickness) had the highest accuracy $\left(M=-183.298+2.272 T+1.286 W+1.414 T\right.$ with $R^{2}=0.96$ and $\left.R S E=4.44\right)$. The external 'Falcato' stiffness was the lowest among the varieties ranged from 6.31-7.01 N.mm${ }^{-1}$ whereas the most stiffness was related to the green ripeness.
\end{abstract}

Keywords: Elasticity modulus, image processing, mechanical properties, modeling, physical properties, tomato

\section{Nomenclature}

\begin{tabular}{|c|c|c|c|}
\hline$L$ & Length (mm) & $T F$ & Flesh thickness (mm) \\
\hline$W$ & Width (mm) & $T S S$ & Total soluble solids \\
\hline$T$ & Thickness (mm) & $\mu$ & Poisson ratio \\
\hline$M$ & Fresh fruit mass (gr) & $\rho_{w}$ & Water density $\left(\mathrm{gr}_{\mathrm{cm}} \mathrm{cm}^{-3}\right)$ \\
\hline$M_{c}$ & Moisture content (\%) & $F_{\max }$ & Maximum applied force $(\mathrm{N})$ \\
\hline$W_{d}$ & Dry weight (gr) & $D_{p}$ & Probe penetration (mm) \\
\hline$W_{t}$ & Wet weight (gr) & $C_{n}$ & Amount of cavity (mm) \\
\hline$W T$ & Tail weight (gr) & $r$ & Probe radius $(\mathrm{mm})$ \\
\hline$S$ & Surface area calculated using a disk technique $\left(\mathrm{mm}^{2}\right)$ & $E$ & Elasticity modulus ( Mpa) \\
\hline$V$ & Volume measured using water displacement method $\left(\mathrm{cm}^{3}\right)$ & Stif & Stiffness (N.mm $\left.{ }^{-1}\right)$ \\
\hline$V_{s}$ & Volume calculated using a disk technique $\left(\mathrm{cm}^{3}\right)$ & Stif $_{e}$ & External stiffness (N.mm $\left.{ }^{-1}\right)$ \\
\hline$D_{g}$ & Geometric diameter $(\mathrm{mm})$ & Stif $_{i}$ & Internal stiffness (N.mm $\left.{ }^{-1}\right)$ \\
\hline$S_{g}$ & Special mass or density $\left(\right.$ gr. $\left.\mathrm{cm}^{-3}\right)$ & $d f$ & Degree of freedom \\
\hline Sph & Sphericity & $R^{2}$ & Root square \\
\hline$W_{p f}$ & Weight of Beaker and water (gr) & $A R^{2}$ & Adjusted root square \\
\hline$W_{p f s}$ & Compound weight (water, beaker, fruit) (gr) & $R S E$ & Root square error \\
\hline
\end{tabular}

\section{Introduction}

Tomato (Lycopercicomesculentum) is classified under subfamily of the Solanaceae. It is a self-fertile vegetable and has 4-6 percent crossbreeding. Tomato fruit is one of the most consuming vegetables used as fresh, dried or processed fruit for human nutrition and has secondary important in its family (Delina Felix \& Mahendran, 2009).

At present, tomato harvesting and processing are mostly manual furthermore by increasing tomato use for large industries, it is required sufficient knowledge of physical and mechanical properties of the tomato to design some 
proper machines for harvesting, grading, cleaning, packaging, and transporting (Baryeh \& Mangope, 2002; Perez et al., 2007; Mahmoodi et al., 2011). In these processes, the tomatoes are exposed to mechanical loading. This can lead to puncture injuries such as makes a hole in tomato with stem, bruises or cuts, all causing qualitative and quantitative losses (Tianxia et al., 2002; Mazaheri Tehrani, 2007). Researchers have spent a lot of their time and efforts to reduce horticultural losses (Tabatabaeefar \& Rajabpour, 2005). Thus, by performing studies on physical and mechanical properties of tomatoes and effective parameters on them and with aid of obtained information, it can be possible to design mechanical systems for processing tomatoes, therefore by decreasing losses in different process sectors, increase the production output. Some knowledges of physico-mechanical properties of agro-food materials are valuable because they are needed as inputs to model the quality and behavior of products in pre-harvest, harvest and post-harvest (Mohsenin, 1986; Nesvadba et al., 2004; Mahmoodi, 2008). For example, the fruit size estimation is importantly needed for planning the packaging, transportation and marketing operations (Tabatabaeefar et al., 2000) and is importantly quality parameters for evaluation by consumer preference (Sadrnia et al., 2007). The size of an agricultural produce is frequently represented by its mass because it is relatively simple to measure. However, volume-based sorting may provide a more efficient method than mass sorting. In addition, the mass of agricultural produce can be estimated from volume if the density of the produce is known. A method to determine the fruit volume is based on using the outer dimensions (Ngouajio et al., 2003; Farahmand, 2008). However, measuring the dimensions using a caliper, subject to human error, may not be an efficient and practical approach to estimate volume, particularly in sorting large quantities of fruit in distribution terminals (Sadrnia et al., 2007).

Nowadays, the use of image processing is gaining interest for the surface area and volume determination of fruit. Sabliov et al. (2002) used an image processing algorithm to determine the surface area and volume of axisymmetric agricultural products. Rashidi and Seifi (2007) used the methodology developed by Sabliov et al. (2002) to measure the volume of agricultural products. They created a representation of the produce with a set of elementary cylindrical objects and estimated the volume by summing the elementary volumes of individual cylinders. Both Sabliov et al. (2002) and Rashidi and Seifi (2007) reported that this method successfully estimated the surface area and volume of lemons and kiwifruit.

On this basis, the objective of this study was to investigate some physical properties such as dimensions, volume, surface area, mass, weight, flesh thickness, total soluble solids, moisture content, density, cavity, ripeness, and some mechanical properties such as fruit stiffness and elasticity modulus which are important for designing a special machine or analyzing the resulting behavior in transporting products. Furthermore the main properties were modeled using the measured features.

\section{Materials and Methods}

\subsection{Materials}

Five tomato varieties - 'Kariz', 'Darbigo', 'Falkato', 'Newton', and 'Shaqayeq' - for three ripeness levels - green, pink, and red - used in this study (Figure 1) obtained from greenhouse of Kesht Nesha Jonoub located at Shahreza, grown at similar conditions. The samples were around full maturity size cleaned manually to remove all foreign matter, dust, dirt, injured samples. Through a completely random factorial design test, effects of independent factors of greenhouse such as tomato varieties and ripeness levels of product at the time of harvesting on physical and mechanical properties of tomato fruit were identified. In this experiment, 15 replications were considered for each test (McGlone \& Jordan, 2000). The tests were carried out at $21 \pm 1{ }^{\circ} \mathrm{C}$ and relative humidity of $30 \% \pm 1 \%$ of environment (Papadopoulou \& Manolopoulou, 1990).

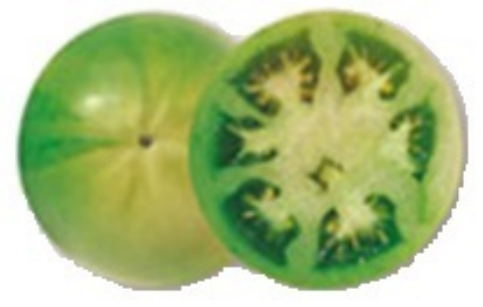

(a)

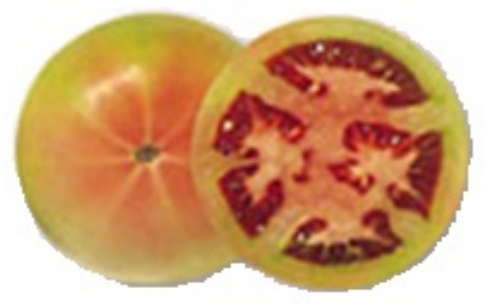

(b)

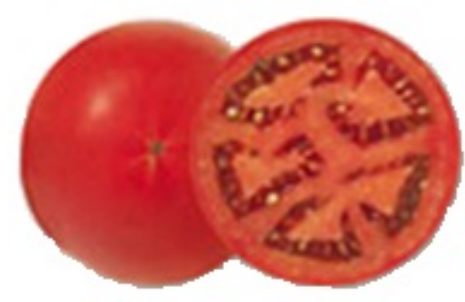

(c)

Figure 1. Three Ripeness Levels of Tomato Fruit used in this Study (a) Green Tomato; (b) Pink Tomato; (c) Red 
Tomato

\subsection{Measured Physical Properties}

Fresh fruit mass $(M)$ or Wet weight $\left(W_{t}\right)$ : The weight of all samples was measured by an electronic balance (R \& D6000i, Japan) with accuracy of $0.01 \mathrm{gr}$ and then the results were recorded in an Excel file.

Dry weight $\left(W_{d}\right)$ : The fresh tomato samples were held $72 \mathrm{~h}$ at $60-70^{\circ} \mathrm{C}$ inside a laboratory oven (MEMERT 500, Germany) (McGlone et al., 2002), then the dried samples were taken out and weighed by the electronic balance.

Tail weight (WT): Tomato fruit tails were cropped from the fruit and freshly weighted using the electronic balance.

Volume $(V)$ : The water displacement method was used, for determining a $1000 \mathrm{cc}$ scaled cylinder was used. First, the cylinder was filled with $500 \mathrm{cc}$ of water and the weight of cylinder with $500 \mathrm{cc}$ water $\left(W_{p f}\right)$ was determined. Then the sample was immersed by means of a needle without the fruit touching the bottom of the beaker, and the weight of the water, beaker, and fruit combination $\left(W_{p f s}\right)$ was measured. In this case, the difference between the two weights was equal to floating force applied from liquid to the sample and the $V$ was obtained by dividing floating force to water density (Stroshine \& Hamann, 1994), so the fruit $V$ was calculated from Equation (1).

$$
V=\frac{\left(W_{p f s}-W_{p f}\right)}{\rho_{w}}
$$

Where, $\rho_{w}$ is water density

Special mass or density $\left(S_{g}\right)$ : The fruit special mass was calculated with equation (2):

$$
S_{g}=\frac{M}{V}
$$

Dimensions: To determine these features, the image processing techniques were used (Mahmoodi et al., 2007 \& 2011). Some standard pictures from the tomato samples were photographed using an image capturing system (see Figure 2). A digital color camera (Model G7 Canon) with resolution of $480 \times 640$ pixels was used to record the images from two vertical sides of directionally fixed tomatoes as shown in Figures 2 and 3(a). The camera was located vertically over the imaging box at a distance of $30 \mathrm{~cm}$ of the tomato samples. The samples were placed on a textile with back color to be easily subtracted by standard segmentation routines because of the difference in color between background and the tomato sample using Matlab (7.8) software. The images were subdivided until the interested objects can be distinguished from their background. In segmentation algorithms, the thresholding and region growing were assayed. To determine the features, threshold values were calculated according to the area difference between objects in the images which were labeled. In this research a demo was developed by using Matlab (7.8) software to extract the final tomato images after filtering and processing and then the features were determined. The images were converted to gray scale images then the binary images were obtained using a random threshold (it was 0.35 see in 'Figure 2') and the holes of the tomatoes in the images were filled. The images were labeled and the main thresholds were calculated according to maximum object area The noises of the background of binary images were removed and final binary images were obtained then some features such as length $(L)$, width $(W)$, thickness $(T)$ and geometric diameter $\left(D_{g}\right)$ of the tomatoes were determined from the images, illustrated as pixel unit converted to SI units and saved as an Excel file.

Sphericity (Sph): The most common method to calculate $S p h$ coefficient is to assume the sample as an ellipsoid. By dividing the ellipsoid volume with $D_{g}$ to the volume of the sphere circumambient to tomato with $L$, the $S p h$ coefficient can be calculated as (Stroshine \& Hamann, 1994):

$$
\text { Sph. }=\frac{D_{g}}{L}
$$

Moisture content $\left(M_{c}\right)$ : The samples $M_{c}$ were measured based on wet weight $\left(W_{t}\right)$. First, the container weight, and the wet sample with container weight were measured using the digital balance ( $W_{t}=$ difference between these two weights). Then the samples were held for $72 \mathrm{~h}$ at $60-70^{\circ} \mathrm{C}$ inside a laboratory oven (MEMERT 500, Germany) (McGlone et al., 2002). Afterwards, the samples were taken out and were located in desiccator for 15 min and after that the samples were weighed once more and the weight of container and the dried sample were determined. Then by means of equation $4, M_{c}$ on wet basis for each sample can be calculated (Stroshine \& Hamann, 1994). 


$$
M_{C}=\frac{W_{t}-W_{d}}{W_{t}} \times 100
$$

Volume $\left(V_{S}\right)$ and surface area $(S)$ : The outline images of each tomato (Figure 2) were used to calculate $V_{S}$ and $S$ with the disk technique (Rashidi \& Seifi, 2007). Each two dimensional outline image of tomato was assumed to be composed of individual rectangular elements as shown in figure 4 . Revolving the height of each rectangular element around the $\mathrm{x}$-axis produces a cylindrical disk with a diameter of $\Delta y$. The volume of each cylindrical disk $\left(V_{i}\right)$ is equal to the cross sectional area of the disk $\left(A_{i}\right)$ times the thickness of the disk $(\Delta x)$. Equation (5) shows the cross-sectional area of a cylindrical disk and the volume of the same disk. Furthermore the surface area of each cylindrical disk $\left(S_{i}\right)$ is equal to perimeter of the disk $\left(P_{i}\right)$ times the thickness of the disk $(\Delta x)$ (Equation 6$)$.

$$
\begin{array}{clc}
A_{i}=\pi\left(\frac{\Delta y}{2}\right)^{2} & V_{i}=A_{i} \Delta x & V_{\text {dtotal }}=\sum V_{i} \\
P_{i}=\pi \Delta y & S_{i}=P_{i} \Delta x & S_{\text {dtotal }}=\sum S_{i}
\end{array}
$$

The program developed in Matlab (7.8) software considered each disk as having a thickness of 1 pixel and used an algorithm to determine the major and minor diameters and calculate the mean diameter of each disk. Using the mean diameter, the $S$ and $V_{S}$ of each disk was calculated. The $S$ and $V_{S}$ of each disk was then summed to estimate the total $S$ and $V_{S}$ as shown in Equations (5 and 6). Finally, the same conversion factor was used to estimate the $S$ and $V_{S}$ of each tomato.

Flesh thickness $(T F)$ : In order to measure $T F$ of each fruit, a digital caliper with $0.01 \mathrm{~mm}$ precision was used. First, a longitudinal profile of the fruit was prepared as shown in Figure 3(b) and then the $T F$ of the fruit was measured (Rafiee et al., 2007).

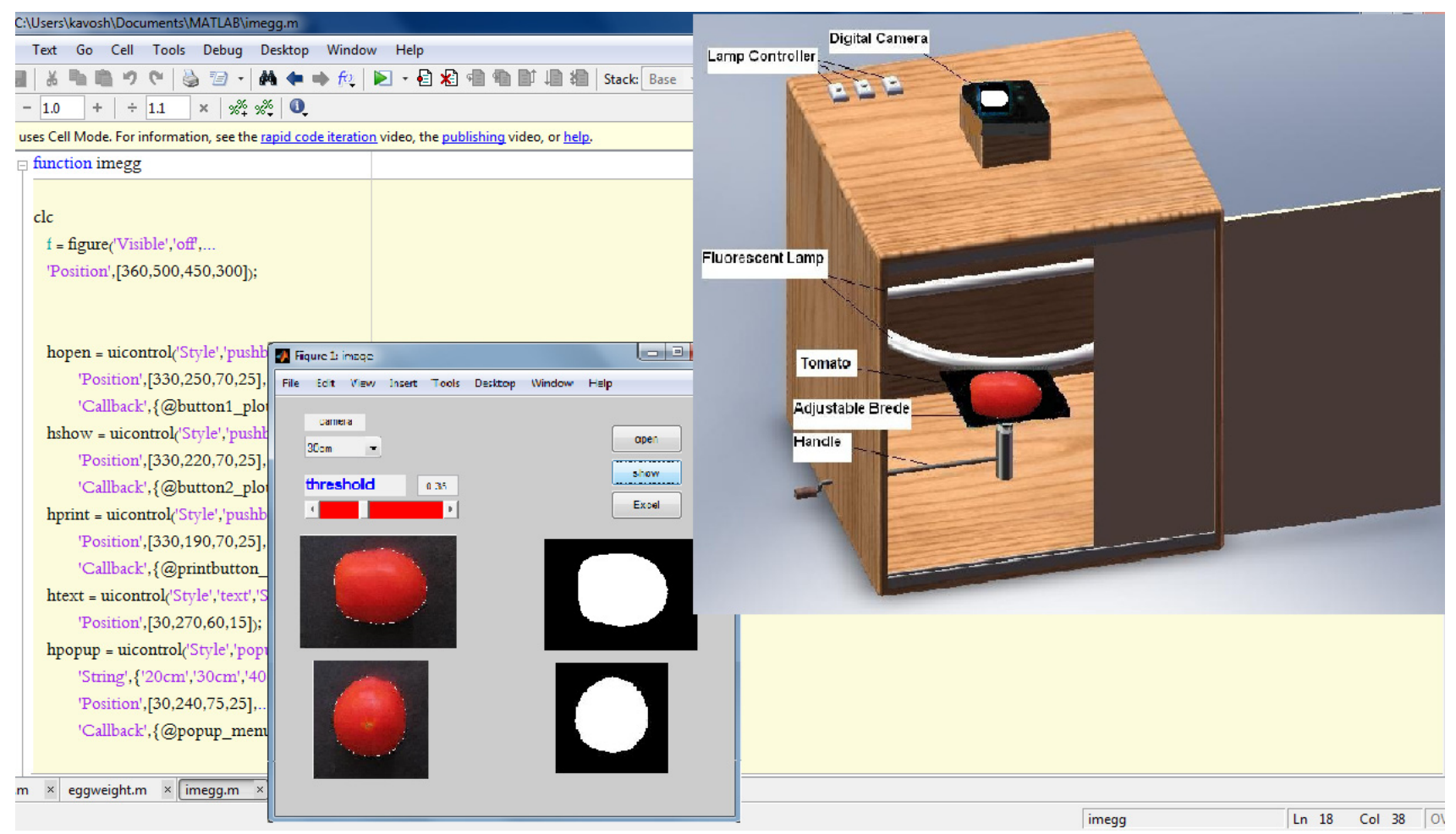

Figure 2. Demo used to Determine the Dimensions of Tomato Fruit (The Random Threshold Was 0.35 and the Camera Distance Was $30 \mathrm{~cm}$ ) and the Schematic of Light Box with Adjustable Light and Changeable Distance

(Camera was Located over the Box) 


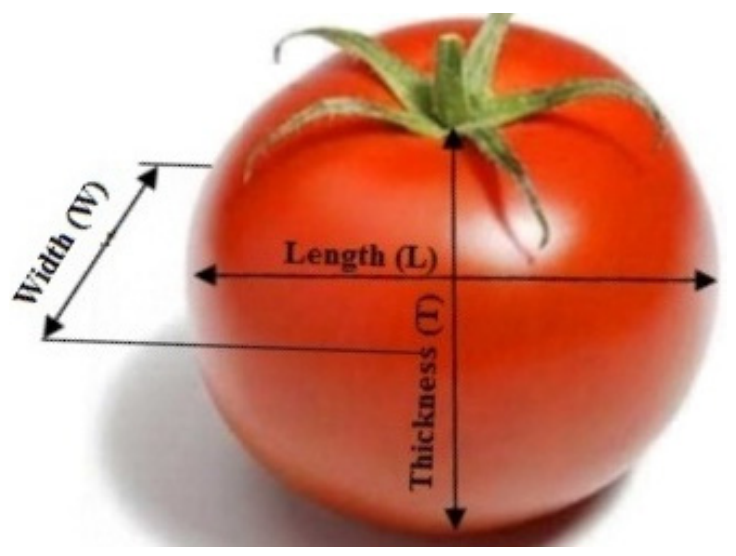

(a)

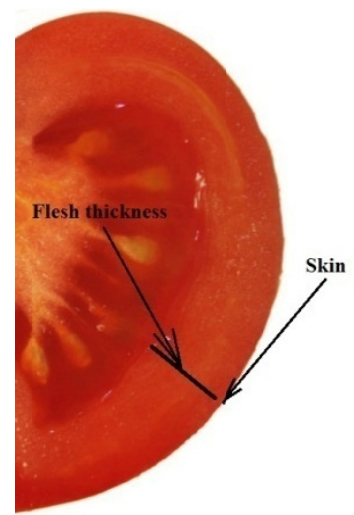

(b)

Figure 3. (a) Three Measured Dimensions of Tomato Fruit, Length $(L)$, Width $(W)$ and Thickness $(T)$; (b) A Longitudinal Profile of Tomato Fruit to Determine the Flesh Thickness

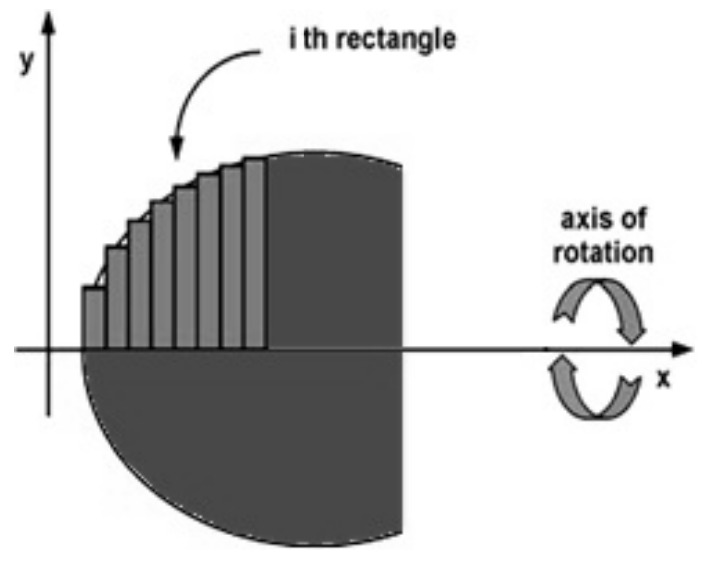

(a)

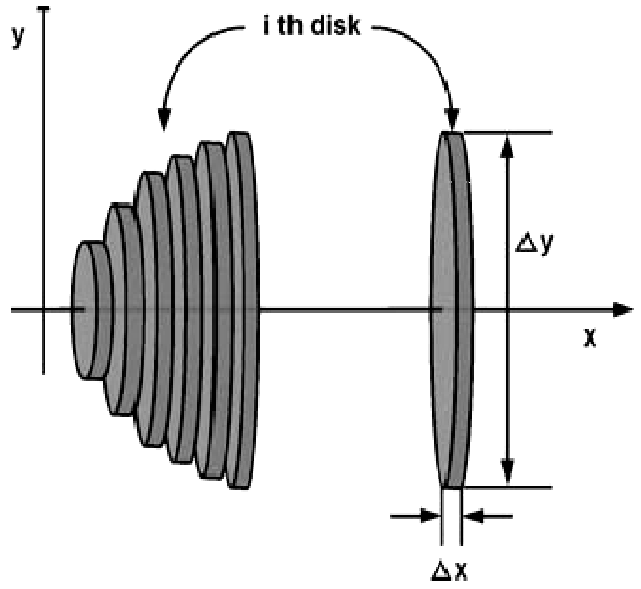

(b)

Figure 4. (a) The Outline Image of the Tomato Was Assumed to be Composed of Individual Rectangular Elements; (b) Revolving each Element around the x-Axis Generated Cylindrical Disks

Total soluble solids (TSS): A digital laboratory refractometer, as an accurate method, was used to measure TSS of samples. Ten mm from each side and both ends of the samples was cut and by means of the refractometer (ATAGO DR-A1, Japan), TSS was determined (McGlone et al., 2002).

Amount of cavity $\left(C_{n}\right)$ : Fruit receptacle cavity was measured as described by Robbins and Moore (1990). The cavity was measured for all five varieties in three ripeness and mean of the five fruit measurements were used for data analyses.

\subsection{Mechanical Properties}

Fruit stiffness (Stif): The fruit Stif was measured in two types, external and internal. To determine the internal stiffness $\left(\right.$ Stif $\left._{i}\right)$, the skin of an area of the samples was removed and the probe penetrated inside the unskin part of the samples. But in external stiffness $\left(\right.$ Stif $\left._{e}\right)$ measurement, pressures can be applied from different zones on the fruit skin. According to the references of fruit Stif determination, the suitable probe diameter was $8 \mathrm{~mm}$ (Anonymous, 2002; Mahmoodi, 2008) and the penetrating duration for depth of 4-5 mm was 2-3 seconds (Anonymous, 2004).The amount of Stif - external and internal - was determined at four locations, head, bottom, and two symmetric points of each sample and finally the average of all four point Stifes was calculated. An apparatus was manufactured as shown in figure 5 and a $500 \mathrm{~N}$ loadcell with $0.001 \mathrm{~N}$ precision was put on the apparatus with a pawl, furthermore a micrometer was timely used to measure the tomato deformation (Figure 5). The loadcell was connected to a PC with a special cable and the data were recorded with its software (Data 
collection speed of this device was $200 \mathrm{~Hz}$ ). The equivalent force for penetration of $4-5 \mathrm{~mm}$ (measured with micrometer) was considered as Stif index (White et al., 2005).

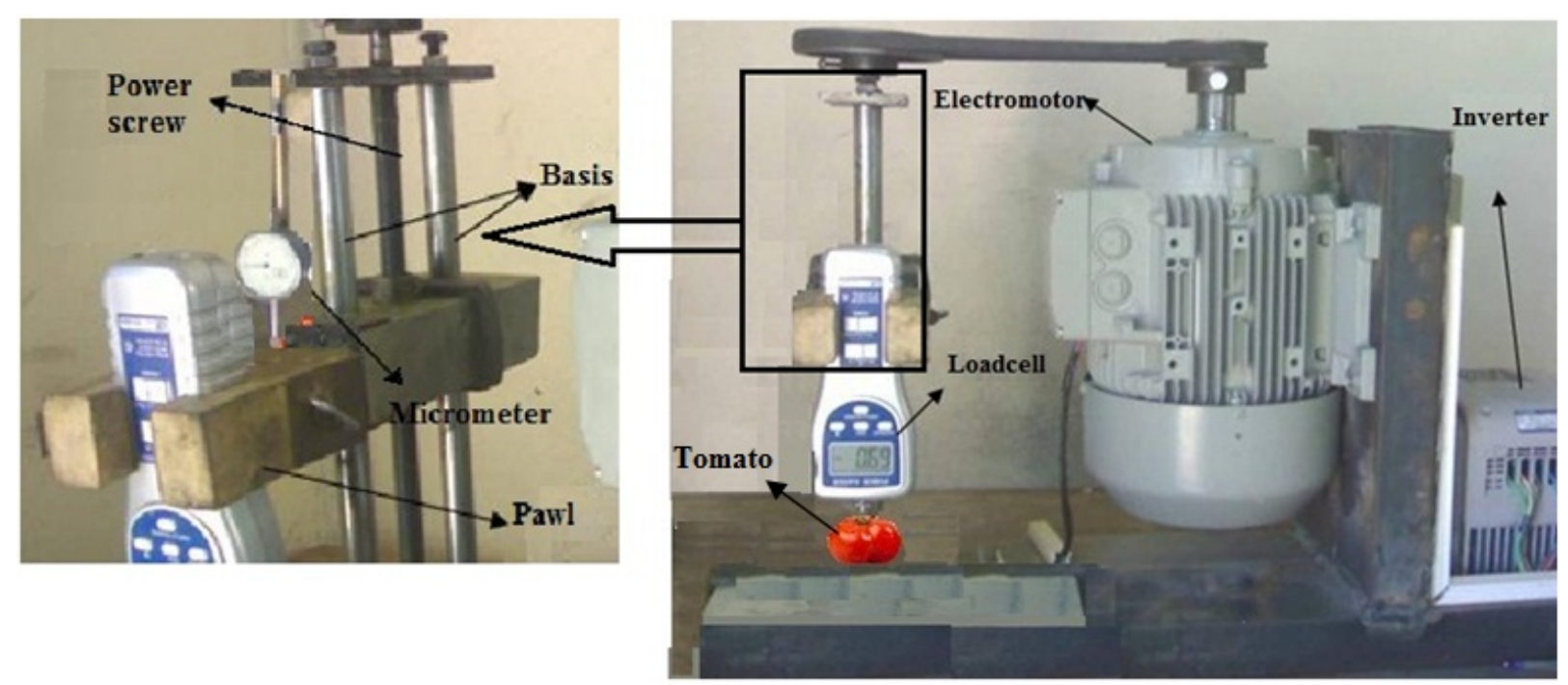

Figure 5. Manufactured apparatus to determine the tomato rupture force

Elasticity modulus (E): To determine this feature, the Bussinesk method was applied. In this method, by pressing a probe cylinder on top of the sample, given the maximum applied force $\left(F_{\max }\right)$ and probe penetration $\left(D_{p}\right)$ inside the sample, the fruit $E$ was calculated from Equation 7. In this equation the Poisson ratio $(\mu)$ was supposed to be 0.3 due to different sources.

$$
E=\frac{F_{\max }}{D_{p}} \times \frac{\left(1-\mu^{2}\right)}{2 r}
$$

\section{Results and Discussion}

\subsection{Effect of Variety and Fruit Ripeness on Tomato Physical Properties}

Volume $(V)$, Wet weight $\left(W_{t}\right)$, Dry weight $\left(W_{d}\right)$, Tail weight $(W T)$, and Density $\left(S_{g}\right)$ : The results of variance analysis of physical properties (Table 1) showed that the fruit ripeness had significantly affected the fruit $V, W_{t}$, and $W_{d}$ at level of $1 \%$ for the varieties, while there were no significant effects on $W T$ and $S_{g}$. Also it was signified that the mutual effect of variety-ripeness on $S_{g}$ was not significant while the variety had significant effects on $S_{g}$ at level of 5\%. The variety and ripeness separately had significantly affected the other parameters at $\mathrm{P}<0.01$.

Table 1. Effect of variety and ripeness on wet weight, dry weight, volume, density, and tail weight (Variance analysis)

\begin{tabular}{|c|c|c|c|c|c|c|}
\hline \multicolumn{5}{|c|}{ Mean squares } & \multirow[b]{2}{*}{ df } & \multirow{2}{*}{$\begin{array}{l}\text { Variation } \\
\text { source }\end{array}$} \\
\hline$W T(g r)$ & $W_{t}(g r)$ & $W_{d}(g r)$ & $V\left(\mathrm{~cm}^{3}\right)$ & $\begin{array}{c}S_{g} \\
\left(\text { gr.cm }^{-3}\right)\end{array}$ & & \\
\hline $0.696^{* *}$ & $7140_{*} 896^{\circ}$ & $6.039^{* *}$ & $8849.549^{\circ}$ & $0.006^{*}$ & 4 & Variety \\
\hline $0.013^{\text {ns }}$ & $7241_{*} 009^{*}$ & $6.191^{* *}$ & $8479.812^{*}$ & $0.005^{\mathrm{ns}}$ & 2 & Ripeness \\
\hline $0.136^{* *}$ & $1428_{*} .482^{*}$ & $4.718^{* *}$ & $1623_{*} .679^{\circ}$ & $0.004^{\text {ns }}$ & 8 & $\begin{array}{l}\text { Variety-Ri } \\
\text { peness }\end{array}$ \\
\hline 0.026 & 321.327 & 1.249 & 357.718 & 0.007 & 327 & Error \\
\hline
\end{tabular}

${ }^{* *}$ Significant level at $1 \% ;{ }^{*}$ Significant level at $5 \% ;{ }^{\text {ns }}$ non significant. 
By performing the multi-domain Duncan test, it was obvious that the $W_{\mathrm{t}}$ and $V$ of the varieties had no significant differences at level of $5 \%$ (Tables 2). The maximum and minimum $W_{t}$ and $V$ averages were related to 'Kariz' and 'Darbigo' varieties, respectively. It is signified in table 2 that the maximum and minimum values of $W_{d}$ were related to 'Kariz' and 'Darbigo' varieties, respectively. Therefore, it appears that the 'Kariz' variety was suitable for tomato paste industry (Thakur et al., 1996) documented that total solids - consisted of soluble solids and insoluble solids - are one the mainly quality factors and have an important role in tomato production). Furthermore it is shown that the order of variety $W_{t}$ differences was similar to $W_{d}$.

Table 2. Comparison of weight and volume averages for the variety and ripeness traits by Duncan test

\begin{tabular}{|c|c|c|c|c|}
\hline \multicolumn{4}{|c|}{ Average } & \multirow{2}{*}{$\begin{array}{c}\text { Variation } \\
\text { source }\end{array}$} \\
\hline$W T(g r)$ & $W_{t}(g r)$ & $W_{d}(g r)$ & $V\left(\mathrm{~cm}^{3}\right)$ & \\
\hline & & Variety & & \\
\hline $0.665^{\mathrm{c}}$ & $102.284^{\mathrm{c}}$ & $4.803^{b}$ & $107.840^{\mathrm{c}}$ & 'Kariz’ \\
\hline $0.651^{c}$ & $77.930^{\mathrm{a}}$ & $3.984^{\mathrm{a}}$ & $80.880^{\mathrm{a}}$ & 'Darbigo' \\
\hline $0.365^{\mathrm{a}}$ & $83.994^{\mathrm{a}, \mathrm{b}}$ & $4.559^{\mathrm{a}, \mathrm{b}}$ & $85.880^{\mathrm{a}, \mathrm{b}}$ & 'Falcato' \\
\hline $0.750^{c}$ & $89.135^{\mathrm{b}}$ & $4.767^{\mathrm{a}, \mathrm{b}}$ & $91.970^{\mathrm{b}}$ & 'Newton' \\
\hline \multirow[t]{2}{*}{$0.471^{b}$} & $82.851^{\mathrm{a}, \mathrm{b}}$ & $4.405^{\mathrm{a}, \mathrm{b}}$ & $86.620^{\mathrm{a}, \mathrm{b}}$ & 'Shaqayeq' \\
\hline & & Ripeness & & \\
\hline $0.594^{\mathrm{a}}$ & $82.747^{\mathrm{a}}$ & $4.443^{\mathrm{a}}$ & $86.570^{\mathrm{a}}$ & Green \\
\hline $0.571^{\mathrm{a}}$ & $83.148^{\mathrm{a}}$ & $4.147^{\mathrm{a}, \mathrm{b}}$ & $85.560^{\mathrm{a}}$ & Pink \\
\hline $0.583^{\mathrm{a}}$ & $96.555^{\mathrm{b}}$ & $4.690^{\mathrm{b}}$ & $101.180^{\mathrm{b}}$ & Red \\
\hline
\end{tabular}

Averages with similar letters had no significant differences at level of $5 \%$.

In general, variable environment conditions and non-hybrid varieties have great effects on fruit shape and may cause dissimilarity in fruit sizes on tomato bush, which is also the same during different growth phases (Mazaheri Tehrani, 2007). In this study, it was shown that during growth season, there was no significant differences between $W_{t}$ and $V$ for green and pink colors, while for red tomato, $W_{t}$ and $V$ increased instantaneously $(\mathrm{P}<0.05)$. The experiments showed that the tomato $W_{t}$ and $V$ increased with maturity levels, which indeed the increased $W_{t}$ and $V$ during pink to light red was obvious (Table 2). After considering that the $S_{g}$ increased during maturity levels, it could be stated that the increasing speed of $M$ was higher than $V$. As it is shown for different ripeness levels in Table 2 the $W_{d}$ for green and pink colors could be both put in a same category or two different ones, while the $W_{t}$ for green and pink colors were at the same category. It is noticed that the $W_{t}$ of green color ripeness was lower than pink, while the $W_{d}$ of pink color was lower than green. This was probably due to more water absorption during this phase and an increase in $W_{t}$ was not because of an increase in $W_{d}$ of fruits.

Dimensions and sphericity $(S p h)$ : The results of variance analysis of physical properties showed that the fruit ripeness and variety had significant effects at $\mathrm{P}<0.01$ on $S p h$ and dimensions. Multi-domain Duncan test showed in table 3 document that the maximum averages of $L, W, T, D_{g}$, and $S p h$ were measured to 'Kariz' variety and the minimum averages of the $L, W$, and $D_{g}$ were measured to 'Darbigo' variety. It has been researched by Mazaheri Tehrani et al. (2003) proving the tomato variety affects Sph. Generally, the oval shaped tomatoes have more insoluble solids and their juice percentage and Brix degree are lower than round samples. Furthermore the oval shaped tomatoes have more Pectin than round varieties which increases their viscosity (Mazaheri Tehrani et al., 2003). However, oval shaped tomatoes are also suitable for peeled tomato conserves because of its spatial shape and eliminating gaps inside the cans (Mazaheri Tehrani, 2007). In this case, the resulted tomato paste would have better taste and color due to round varieties, and solids and viscosity due to oval ones. After considering, the 'Kariz' and 'Darbigo' varieties with more $S p h 90 \%$ were determined as round and 'Falcato' variety with $88 \%$ as oval (Table 3). As it is shown in table 3 the maximum and minimum averages of $L, W$, and $D_{g}$ were related to red and pink ripeness, respectively, and just $T$ average was the minimum for green and maximum for red ripeness; which means, by fruit growth from green to pink, the $L, W$, and $D_{g}$ decreased and only the $T$ increased. Due to this result, the minor decrease in fruit $V$ during green to pink phase was justifiable. The physical 
properties including dimensions and apparent shape properties were differenced among the varieties. Therefore these properties could be separated the tomato varieties. This is applicable for designing devices dealing with the fruit shape.

Table 3. Comparison of dimensional feature averages for the variety and ripeness traits by Duncan test

\begin{tabular}{|c|c|c|c|c|c|}
\hline \multicolumn{5}{|c|}{ Averages } & \multirow{2}{*}{$\begin{array}{l}\text { Variation } \\
\text { source }\end{array}$} \\
\hline$L(\mathrm{~mm})$ & $W(\mathrm{~mm})$ & $T(\mathrm{~mm})$ & $D_{g}(\mathrm{~mm})$ & Sph & \\
\hline & & Variety & & & \\
\hline $61.295^{\mathrm{c}}$ & $59.224^{\mathrm{d}}$ & $47.034^{\mathrm{d}}$ & $55.447^{\mathrm{c}}$ & $0.906^{\mathrm{c}}$ & 'Kariz' \\
\hline $56.562^{\mathrm{a}}$ & $54.332^{\mathrm{a}}$ & $43.479^{\mathrm{b}}$ & $51.092^{\mathrm{a}}$ & $0.904^{\mathrm{c}}$ & 'Darbigo' \\
\hline $58.792^{\mathrm{b}}$ & $56.520^{\mathrm{b}, \mathrm{c}}$ & $42.255^{\mathrm{a}}$ & $52.075^{\mathrm{a}}$ & $0.886^{\mathrm{a}}$ & 'Falcato' \\
\hline $59.707^{\mathrm{b}, \mathrm{c}}$ & $57.947^{\mathrm{c}, \mathrm{d}}$ & $44.606^{\mathrm{c}}$ & $53.631^{\mathrm{b}}$ & $0.898^{\mathrm{b}, \mathrm{c}}$ & 'Newton' \\
\hline \multirow[t]{2}{*}{$58.504^{\mathrm{b}}$} & $56.273^{b}$ & $43.224^{\mathrm{a}, \mathrm{b}}$ & $52.184^{\mathrm{a}}$ & $0.892^{\mathrm{a}, \mathrm{b}}$ & 'Shaqayeq' \\
\hline & & Ripeness & & & \\
\hline $58.390^{\mathrm{a}}$ & $56.369^{\mathrm{a}}$ & $43.228^{a}$ & $52.188^{\mathrm{a}}$ & $0.894^{\mathrm{a}}$ & Green \\
\hline $57.889^{\mathrm{a}}$ & $55.826^{\mathrm{a}}$ & $43.576^{\mathrm{a}}$ & $51.996^{\mathrm{a}}$ & $0.899^{\mathrm{a}, \mathrm{b}}$ & Pink \\
\hline $60.463^{\mathrm{b}}$ & $58.148^{\mathrm{b}}$ & $45.965^{\mathrm{b}}$ & $54.485^{\mathrm{b}}$ & $0.902^{\mathrm{b}}$ & Red \\
\hline
\end{tabular}

Averages with similar letters had no significant differences at level of $5 \%$.

Surface area $(S)$, Volume $\left(V_{s}\right)$, Flesh thickness (TF), Total soluble solids (TSS), and cavity $\left(C_{n}\right)$ : The variance analysis results in table 4 show how the variety had significant effects on $S, T S S, T F, C_{n}$, and $V_{s}$ and the fruit ripeness had significant effects on $S, T S S$, and $V_{s}(\mathrm{P}<0.01)$. Through a multi-domain Duncan test (Table 5), it was signified that the maximum and minimum $S$ and $V_{s}$ were calculated to 'Kariz' and 'Darbigo' varieties, respectively. Obviously, the reason of the decreasing $S$ and $V_{s}$ in different ripeness levels was related to decrease the main diameters $(L, W)$. The correlation coefficient between the $V$ and $V_{s}$ illustrated in Table $9(=0.98)$ show that the disk technique can calculate the volume very well.

Table 4. Variance analysis of flesh thickness, volume and surface area calculated using the disk technique, cavity, and total soluble solids for the ripeness and variety traits

\begin{tabular}{ccccccc}
\hline \multicolumn{5}{c}{ Mean Squares } & \multirow{2}{*}{ Variation source } \\
\cline { 1 - 5 }$S\left(\mathrm{~mm}^{2}\right)$ & $V_{s}\left(\mathrm{~cm}^{3}\right)$ & $T F(\mathrm{~mm})$ & $T S S$ & $C_{n}(\mathrm{~mm})$ & & \\
\hline $1.894 \mathrm{E}+07^{* *}$ & $3436.614^{* *}$ & $10.463^{* *}$ & $80.561^{* *}$ & $1.610^{* *}$ & 4 & Variety \\
$2.696 \mathrm{E}+07^{* *}$ & $4646.674^{* *}$ & $0.887^{\mathrm{ns}}$ & $9.787^{* *}$ & $0.206^{\mathrm{ns}}$ & 2 & Ripeness \\
$4.459 \mathrm{E}+06^{* *}$ & $849.291^{* *}$ & $1.130^{\mathrm{ns}}$ & $6.287^{* *}$ & $0.380^{\mathrm{ns}}$ & 8 & Ripeness-Variety \\
$1.213 \mathrm{E}+06$ & 212.035 & 0.738 & 0.347 & 0.398 & 313 & Error \\
\hline
\end{tabular}

${ }^{* *}$ Significant level at $1 \% ;{ }^{*}$ Significant level at $5 \% ;{ }^{\text {ns }}$ non significant.

Based on the results, the maximum and minimum $T F$ were determined for 'Shaqayeq' and 'Falcato' varieties, respectively, also the maximum and minimum TSS averages were related to 'Kariz' and 'Shaqayeq' varieties, respectively. The 'Kariz' variety with the most TSS caused an increase in output viscosity, total product quality, and a decrease of water evaporation and energy consumption in tomato paste industry (Bourne, 1983). It is shown in Table 5 that both the TSS had no significant differences $(\mathrm{P}<0.05)$ with $T F$ for all varieties and $S, V_{s}, C_{n}$ with each other. The Duncan test results in Table 5 showed that the $C_{n}$ and TSS had no significant differences $(\mathrm{P}<0.05)$ in different ripeness levels. Furthermore it was indicated that $S$ and $V_{s}$ for green color was higher than pink and the maximum of these parameters were related to red. The other results showed that the maximum and minimum TSS values were determined to green and red, respectively. 
Table 5. Comparison of flesh thickness, volume and surface area calculated using the disk technique, cavity, and total soluble solid averages for the variety and ripeness traits by Duncan test

\begin{tabular}{cccccc}
\hline \multicolumn{5}{c}{ Average } & Variation \\
\cline { 1 - 4 }$S\left(\mathrm{~mm}^{2}\right)$ & $V_{S}\left(\mathrm{~cm}^{3}\right)$ & $T F(\mathrm{~mm})$ & $T S S$ & $C_{n}(\mathrm{~mm})$ & source \\
\cline { 1 - 3 } 9 & & Variety & & & \\
\cline { 3 - 4 } $9415.557^{\mathrm{b}}$ & $86.253^{\mathrm{b}}$ & $5.567^{\mathrm{c}}$ & $3.678^{\mathrm{c}}$ & $3.480^{\mathrm{b}}$ & 'Kariz' \\
$8186.747^{\mathrm{a}}$ & $69.656^{\mathrm{a}}$ & $5.442^{\mathrm{b}, \mathrm{c}}$ & $1.311^{\mathrm{a}}$ & $3.230^{\mathrm{a}}$ & 'Darbigo' \\
$8535.258^{\mathrm{a}}$ & $73.463^{\mathrm{a}}$ & $4.569^{\mathrm{a}}$ & $1.716^{\mathrm{b}}$ & $3.400^{\mathrm{a}, \mathrm{b}}$ & 'Falcato' \\
$9062.067^{\mathrm{b}}$ & $80.896^{\mathrm{b}}$ & $5.216^{\mathrm{b}}$ & $1.654^{\mathrm{b}}$ & $3.590^{\mathrm{b}}$ & 'Newton' \\
$8444.579^{\mathrm{a}}$ & $73.249^{\mathrm{a}}$ & $5.658^{\mathrm{c}}$ & $1.274^{\mathrm{a}}$ & $3.210^{\mathrm{a}}$ & 'Shaqayeq' \\
& & Ripeness & & & \\
\cline { 3 - 4 } $8451.847^{\mathrm{a}}$ & $73.126^{\mathrm{a}}$ & $5.377^{\mathrm{b}}$ & $2.254^{\mathrm{a}}$ & $3.290^{\mathrm{a}}$ & Green \\
$8416.582^{\mathrm{a}}$ & $72.653^{\mathrm{a}}$ & $5.288^{\mathrm{a}}$ & $1.858^{\mathrm{a}}$ & $3.340^{\mathrm{a}}$ & Pink \\
$9228.707^{\mathrm{b}}$ & $83.394^{\mathrm{b}}$ & $5.434^{\mathrm{a}}$ & $1.837^{\mathrm{a}}$ & $3.430^{\mathrm{a}}$ & Red \\
\hline
\end{tabular}

Averages with similar letters had no significant differences at level of $5 \%$.

\subsection{Effect of Variety and Fruit ripeness on Tomato Mechanical Properties}

Elasticity modulus (E): Results obtained from variance analysis showed that the relationship between the $E$ of four tomato sides and variety was statistically significant $(\mathrm{P}<0.01)$. While this parameter in different ripeness and the mutual effect of variety-ripeness was not significant.

Multi-domain Duncan test (Table 6) showed that the maximum and minimum $E$ of head tomatoes were related to 'Darbigo' and 'Newton' varieties, respectively. These values of bottom fruit were measured for 'Darbigo' and 'Falcato' varieties, respectively, also that of both side and four side averages of $E$ were related to 'Kariz' and 'Falcato' varieties, respectively. According to researches the $E$ indicates substance elastic states against static and dynamic load. The above results can conclude that the 'Kariz' variety acts as a spring against impact loads and impact loads have little effect on it and also have a damping condition.

Table 6. Comparison of four side elasticity modulus averages of tomato for the variety traits by Duncan test

\begin{tabular}{ccccc}
\hline \multicolumn{4}{c}{$E$ averages $(M p a)$} & \multirow{2}{*}{ Variety } \\
\cline { 1 - 3 } Head & Bottom & Both sides & Four sides & \\
\hline $0.1765^{\mathrm{c}}$ & $0.1798^{\mathrm{b}}$ & $0.1559^{\mathrm{b}}$ & $0.1670^{\mathrm{c}}$ & 'Kariz' \\
$0.1785^{\mathrm{c}}$ & $0.1806^{\mathrm{b}}$ & $0.1507^{\mathrm{b}}$ & $0.1652^{\mathrm{c}}$ & 'Darbigo' \\
$0.1085^{\mathrm{a}}$ & $0.1007^{\mathrm{a}}$ & $0.0740^{\mathrm{a}}$ & $0.0893^{\mathrm{a}}$ & 'Falcato' \\
$0.1026^{\mathrm{a}}$ & $0.1059^{\mathrm{a}}$ & $0.0769^{\mathrm{a}}$ & $0.0906^{\mathrm{a}}$ & 'Newton' \\
$0.1423^{\mathrm{b}}$ & $0.1553^{\mathrm{b}}$ & $0.1353^{\mathrm{b}}$ & $0.1420^{\mathrm{b}}$ & 'Shaqayeq' \\
\hline
\end{tabular}

Averages with similar letters had no significant differences at level of $5 \%$.

Stiffness (Stif): Variance analysis results showed that the variety had significantly affected Stif $_{e}$ of the samples at four sides and both sides $(\mathrm{P}<0.01)$, while the variety was a significant treatment on all $\mathrm{Stif}_{i}$ at $\mathrm{P}<0.01$. Also the results showed that the four side $S t i f_{\mathrm{i}}$, except fruit bottom, and the four side $S t i f_{\mathrm{e}}$, except fruit head, for all ripeness states were significant at $\mathrm{P}<0.01$ (Table 7). 
Table 7. Effect of variety and ripeness on tomato stiffness (Variance analysis)

\begin{tabular}{|c|c|c|c|c|c|c|c|c|c|}
\hline \multicolumn{8}{|c|}{ Mean Squares of Stiff $\left(N . m^{-l}\right)$} & \multirow{3}{*}{$\mathrm{df}$} & \multirow{3}{*}{$\begin{array}{c}\text { Variation } \\
\text { source }\end{array}$} \\
\hline \multicolumn{4}{|c|}{ Internal } & \multicolumn{4}{|c|}{ External } & & \\
\hline Head & Bottom & Both sides & Four sides & Head & Bottom & Both sides & Four sides & & \\
\hline $7.17^{* *}$ & $13.66^{* *}$ & $5.37^{* *}$ & $6.82^{* *}$ & $2.69^{\mathrm{ns}}$ & $5.27^{\mathrm{ns}}$ & $7.25^{* *}$ & $5.00^{* *}$ & 4 & Variety \\
\hline $4.63^{* *}$ & $0.59^{\mathrm{ns}}$ & $5.56^{* *}$ & $3.08^{* *}$ & $2.52^{\mathrm{ns}}$ & $11.72^{* *}$ & $10.28^{* *}$ & $7.91^{* *}$ & 2 & Ripeness \\
\hline $0.88^{\mathrm{ns}}$ & $1.12^{\mathrm{ns}}$ & $1.87^{* *}$ & $0.99^{* *}$ & $1.68^{\mathrm{ns}}$ & $3.03^{\mathrm{ns}}$ & $6.74^{* *}$ & $3.60^{* *}$ & 8 & Ripeness-Variety \\
\hline 0.68 & 0.71 & 0.39 & 0.24 & 1.75 & 2.03 & 1.70 & 1.37 & 37 & Error \\
\hline
\end{tabular}

${ }^{* *}$ Significant level at $1 \% ;{ }^{*}$ Significant level at $5 \% ;{ }^{\text {ns }}$ non significant.

Table 8. Comparison of four side stiffness averages of tomato for the variety and ripeness traits by Duncan test

\begin{tabular}{|c|c|c|c|c|c|c|c|c|}
\hline \multicolumn{8}{|c|}{ Averages of Stiff $\left(N \cdot \mathrm{mm}^{-1}\right)$} & \multirow{3}{*}{$\begin{array}{l}\text { Variation } \\
\text { source }\end{array}$} \\
\hline \multicolumn{4}{|c|}{ Internal } & \multicolumn{4}{|c|}{ External } & \\
\hline Head & Bottom & Both sides & Four sides & Head & Bottom & Both sides & Four sides & \\
\hline & & & & Variety & & & & \\
\hline $3.5352^{\mathrm{a}, \mathrm{b}}$ & $3.1984^{\mathrm{a}}$ & $3.4399^{\mathrm{b}}$ & $3.4033^{\mathrm{b}}$ & $7.3994^{\mathrm{a}}$ & $8.0750^{\mathrm{a}, \mathrm{b}}$ & $8.0114^{\mathrm{b}}$ & $7.8743^{\mathrm{b}}$ & 'Kariz' \\
\hline $3.3394^{\mathrm{a}, \mathrm{b}}$ & $3.2778^{\mathrm{a}}$ & $2.7521^{\mathrm{a}}$ & $3.0303^{\mathrm{a}, \mathrm{b}}$ & $7.6954^{\mathrm{a}}$ & $8.8637^{\mathrm{b}}$ & $8.1162^{\mathrm{b}}$ & $8.1978^{\mathrm{b}}$ & 'Darbigo' \\
\hline $3.9752^{\mathrm{b}}$ & $2.9777^{\mathrm{a}}$ & $3.4709^{\mathrm{b}}$ & $3.4737^{\mathrm{b}}$ & $6.6511^{\mathrm{a}}$ & $7.0100^{\mathrm{a}}$ & $6.3112^{\mathrm{a}}$ & $6.5709^{\mathrm{a}}$ & 'Falcato' \\
\hline $5.2588^{\mathrm{c}}$ & $5.7354^{\mathrm{b}}$ & $4.4123^{\mathrm{c}}$ & $4.9547^{\mathrm{c}}$ & $7.8951^{\mathrm{a}}$ & $8.4258^{\mathrm{b}}$ & $7.3990^{\mathrm{a}, \mathrm{b}}$ & $7.7797^{\mathrm{b}}$ & 'Newton' \\
\hline \multirow[t]{2}{*}{$3.0571^{\mathrm{a}}$} & $3.2393^{\mathrm{a}}$ & $2.6415^{\mathrm{a}}$ & $2.8949^{\mathrm{a}}$ & $7.6182^{\mathrm{a}}$ & $8.2014^{\mathrm{a}, \mathrm{b}}$ & $7.7171^{\mathrm{b}}$ & $7.8134^{\mathrm{b}}$ & 'Shaqayeq' \\
\hline & & & & Ripeness & & & & \\
\hline $4.5338^{\mathrm{b}}$ & $3.8804^{\mathrm{a}}$ & $3.9316^{\mathrm{b}}$ & $4.0694^{\mathrm{b}}$ & $7.8775^{\mathrm{a}}$ & $9.0318^{\mathrm{b}}$ & $8.1699^{\mathrm{b}}$ & $8.3123^{\mathrm{b}}$ & Green \\
\hline $3.4475^{\mathrm{a}}$ & $3.3987^{\mathrm{a}}$ & $3.0794^{\mathrm{a}}$ & $3.2513^{\mathrm{a}}$ & $7.3286^{\mathrm{a}}$ & $7.9422^{\mathrm{a}}$ & $7.1458^{\mathrm{a}}$ & $7.3906^{\mathrm{a}}$ & Pink \\
\hline $3.4787^{\mathrm{a}}$ & $3.7176^{\mathrm{a}}$ & $2.9287^{\mathrm{a}}$ & $3.2634^{\mathrm{a}}$ & $7.1638^{\mathrm{a}}$ & $7.4439^{\mathrm{a}}$ & $7.1899^{\mathrm{a}}$ & $7.2469^{\mathrm{a}}$ & Red \\
\hline
\end{tabular}

Averages with similar letters had no significant differences at level of $5 \%$.

The multi-domain Duncan test showed that the minimum of all side Stif $f_{\mathrm{e}}$ averages was measured for 'Falcato' variety and there were no significant differences with the other varieties (Table 8). It was indicated that the maximum Stif was totally related to green color ripeness and there were no significant differences between pink and red colors. This considers that the required force for penetrating into immature tomato skin is more. Tianxia et al. (2002) also obtained similar results with Instron device for evaluating tomato anatomic tissues during maturity. Generally, during growth phases of fruit, some important changes occur in middle layer of cell wall. First, the cell wall turns to a solution and by developing of maturity level, the wall breakup increases which in fully mature fruits causes walls to become fragile and thin. It can be suggested that cavity tissues filled jellylike in ripe fruit, has less resistance against deformation. Pericarp and internal epidermis decrease slowly during green to pink phases and then by a rapid fall in skin resistance, decrease too. It seems that the changes of composition and solubility of cell wall polysaccharides impress an important role for softening caused by tomato fruit ripening. Seymour \& Gross (1995) suggested that during tomato fruit maturity, soluble polyuronide is separated from pectic part of cell wall. Huber (1985) reported that pectin breakdown during tomato maturity is considered as the main factor for softening. Kim et al. (1991) stated that during tomato fruit maturity, cell wall galactosyl residues decrease. Galactosyl become isolated from tomato fruit cell wall which greatly affects natural substrates and its activity increases with four times through green maturity-ripening (Kim et al., 1991; Carey et al., 1995). 


\subsection{Modeling Mass and Volume with Dimensions}

The correlation coefficients among the measured parameters were needed to model them with each other. Table 9 shows the Pearson correlation coefficients among the properties and it is obvious that these features had significant correlations with each other.

Table 9. Pearson correlation coefficients among the measured physical properties

\begin{tabular}{|c|c|c|c|c|c|c|c|c|c|c|c|c|c|c|c|}
\hline Source & $M$ & $W_{d}$ & $W T$ & $V$ & $V_{s}$ & $S_{g}$ & $W$ & $T$ & $L$ & $S$ & $D_{g}$ & Sph & $C_{n}$ & $T F$ & TSS \\
\hline$M$ & 1.00 & & & & & & & & & & & & & & \\
\hline$W_{d}$ & $0.80^{* *}$ & 1.00 & & & & & & & & & & & & & \\
\hline$W T$ & $0.44^{*}$ & $0.37^{*}$ & 1.00 & & & & & & & & & & & & \\
\hline$V$ & $0.91^{* *}$ & $0.82^{* *}$ & $0.38^{*}$ & 1.00 & & & & & & & & & & & \\
\hline$V_{s}$ & $0.97^{* *}$ & $0.87^{* * *}$ & $0.49^{*}$ & $0.98^{* *}$ & 1.00 & & & & & & & & & & \\
\hline$S_{g}$ & $0.75^{* *}$ & $-0.09^{\text {ns }}$ & $0.02^{\mathrm{ns}}$ & $-0.26^{*}$ & $-0.30^{*}$ & 1.00 & & & & & & & & & \\
\hline$W$ & $0.89^{* *}$ & $0.62^{* *}$ & $0.25^{*}$ & $0.90^{* *}$ & $0.95^{* *}$ & $-0.10^{\mathrm{ns}}$ & 1.00 & & & & & & & & \\
\hline$T$ & $0.90^{* *}$ & $0.86^{* *}$ & $0.39^{*}$ & $0.90^{* *}$ & $0.88^{* *}$ & $-0.09^{\text {ns }}$ & $0.70^{* *}$ & 1.00 & & & & & & & \\
\hline$L$ & $0.93^{* *}$ & $0.85^{* *}$ & $0.39^{*}$ & $0.92^{* *}$ & $0.95^{* *}$ & $-0.07^{\mathrm{ns}}$ & $0.69^{* * *}$ & $0.96^{* *}$ & 1.00 & & & & & & \\
\hline$S$ & $0.88^{* *}$ & $0.84^{* *}$ & $0.37^{*}$ & $0.83^{* *}$ & $0.98^{* *}$ & $-0.09^{\mathrm{ns}}$ & $0.86^{* *}$ & $0.95^{* *}$ & $0.95^{* *}$ & 1.00 & & & & & \\
\hline$D_{g}$ & $0.88^{* *}$ & $0.84^{* *}$ & $0.37^{*}$ & $0.89^{* *}$ & $0.98^{* *}$ & $-0.09^{\mathrm{ns}}$ & $0.87^{* *}$ & $0.96^{* *}$ & $0.95^{* *}$ & $0.99^{* *}$ & 1.00 & & & & \\
\hline Sph & $-0.10^{\text {ns }}$ & $-0.17^{*}$ & $-0.17^{*}$ & $-0.08^{\text {ns }}$ & $-0.40^{*}$ & $-0.08^{\mathrm{ns}}$ & $0.43^{*}$ & $-0.16^{*}$ & $-0.31^{*}$ & $-0.01^{\text {ns }}$ & $-0.01^{\text {ns }}$ & 1.00 & & & \\
\hline$C_{n}$ & $0.29^{*}$ & $0.28^{*}$ & $0.30^{*}$ & $0.26^{*}$ & $0.77^{* *}$ & $0.04^{\mathrm{ns}}$ & $0.04^{\text {ns }}$ & $0.32^{*}$ & $0.40^{*}$ & $0.28^{*}$ & $0.27^{*}$ & $-0.43^{*}$ & 1.00 & & \\
\hline$T F$ & $0.45^{*}$ & $0.44^{*}$ & $0.17^{*}$ & $0.48^{*}$ & $0.19^{*}$ & $-0.11^{*}$ & $0.51^{* *}$ & $0.47^{*}$ & $0.45^{*}$ & $0.51^{* *}$ & $0.51^{* *}$ & $0.10^{\mathrm{ns}}$ & $-0.14^{*}$ & 1.00 & \\
\hline TSS & $0.29^{*}$ & $0.22^{*}$ & $0.19^{*}$ & $0.30^{*}$ & $0.85^{* *}$ & $-0.06^{\mathrm{ns}}$ & $0.22^{*}$ & $0.26^{*}$ & $0.24^{*}$ & $0.26^{*}$ & $0.26^{*}$ & $0.04^{\mathrm{ns}}$ & $0.15^{*}$ & $0.40^{*}$ & 1.00 \\
\hline
\end{tabular}

${ }^{* *}$ Significant level at $1 \% ;{ }^{*}$ Significant level at $5 \% ;{ }^{\text {ns }}$ non significant.

Usually, the grading and sorting process of fruits is based on $M$ and $V$. Determining these traits in sorting devices is done by measuring dimensions and in equipped devices with machine vision is performed by projected surfaces. According to the high significant correlation between $M$ and $V$ of tomato with dimensions (Table 9), the dimensions were used to estimate the $M$ and $V$ of tomato as the regression models.

Volume models: The $V$ had the correlation coefficients of $(90 \%-92 \%)$ with the dimensions. Thus, for introducing a proper model for $V$ estimation, the dimensions were used as a linear regression (Farahmand, 2008).

$$
V=a+b L+c W+d T
$$

Where $a, b, c$, and $d$ were the model coefficients.

Linear regression models for $V$ estimation of the varieties have been indicated in table 10. Furthermore the coefficient of determination $\left(R^{2}\right)$, adjusted coefficient of determination $\left(A R^{2}\right)$, and root square error $(R S E)$ of each model were presented. As it is shown, the third model had the highest $R^{2}(95 \%)$ and lowest RSE (4.80) among the models and it can be noted that the $V$ estimation from the third equation was the most appropriate model. The F-test in regression analysis signified that these models were significant linear models and using the $\mathrm{T}$-test, all model coefficients were significant at level of $1 \%$. 
Table 10. Regression models for the volume and mass estimation based on the tomato dimensions, volume, density, and dry weight

\begin{tabular}{|c|c|c|c|c|c|}
\hline $\begin{array}{l}\text { Estimated } \\
\text { feature }\end{array}$ & Num & Model & $R^{2}$ & $A R^{2}$ & $R S E$ \\
\hline & & Using dimensions & & & \\
\hline & 1 & $V=-169.897+4.60 T$ & 0.917 & 0.916 & 6.564 \\
\hline \multirow[t]{3}{*}{ Volume } & 2 & $V=-184.722+3.768 T+1.409 \mathrm{~W}$ & 0.944 & 0.942 & 5.442 \\
\hline & 3 & $V=-191.834+1.877 T+1.396 W+1.944 L$ & 0.957 & 0.955 & 4.800 \\
\hline & 1 & $M=-167.751+4.60 L$ & 0.918 & 0.917 & 6.220 \\
\hline \multirow[t]{4}{*}{ Mass } & 2 & $M=-183.914+3.503 L+1.470 \mathrm{~W}$ & 0.953 & 0.951 & 4.758 \\
\hline & 3 & $M=-183.298+2.272 L+1.286 W+1.414 T$ & 0.960 & 0.958 & 4.436 \\
\hline & & Using volume, density and dry weight & & & \\
\hline & 1 & $M=11.465+0.830 \mathrm{~V}$ & 0.810 & 0.809 & 10.947 \\
\hline \multirow[t]{2}{*}{ Mass } & 2 & $M=-103.137+0.928 \mathrm{~V}+109.811 S_{g}$ & 0.979 & 0.979 & 3.603 \\
\hline & 3 & $M=-102.447+0.894 \mathrm{~V}+108.710 S_{g}+0.791 W_{d}$ & 0.980 & 0.980 & 3.575 \\
\hline
\end{tabular}

Mass models: According the correlation coefficients in table 9 , the $M$ had the most correlation coefficient with the dimensions ( $89 \%-93 \%$ ); therefore the $M$ estimation using the dimensions was the most prominent among the models. In order to present a proper model for $M$ estimation based on fruit dimensions, the linear regression was used as (Farahmand, 2008):

$$
M=a+b L+c W+d T
$$

Where $a, b, c$, and $d$ were the model coefficients.

Linear regression models presented in Table 10 were used to estimate the $M$ along with model's $R^{2}, A R^{2}$, and $R S E$. As it is shown, the third model had the highest accuracy $\left(R^{2}=96 \%\right.$ and $\left.R S E=4.44\right)$ and it was the most appropriate model. The T-test showed that all model coefficients were significant at level of $1 \%$.

\subsection{Relation among the Tomato Mass, Volume, Density, and Dry Weight}

The tomato $M$ was significantly high correlated with $V, S_{g}$, and $W_{d}$ (Table 9). Therefore some possible statistical relations were confirmed among these features and three models with stronger estimation were presented. The $M$ regression models with $V, S_{g}, W_{d}$, and their statistical coefficients are shown in Table 10. As it is indicated, the third model had the highest accuracy with the most $R^{2}(98 \%)$ and lowest $R S E(3.5)$ among the models. The F-test of regression analysis showed that the linear models in Table 10 were significant and the T-test showed that all model coefficients were significant at $\mathrm{P}<0.01$.

\section{Conclusion}

Considering the research conducted during the harvesting phase of tomatoes on variety and maturity percentage, it was determined that among the planted varieties in greenhouse, the 'Kariz' variety had the highest $S_{g}$, TSS, and $S p h$ among the varieties, consequently this variety was suitable for tomato paste industry. The results showed that the highest and lowest $V$ were determined for 'Kariz' and 'Derbigo' varieties, respectively; therefore in places where $V$ is a main factor, the minimum and maximum of $V$ can be considered in these varieties. It was appeared that the 'Shaqayeq' variety due to its bigger $C_{n}$ and $T F$ has the best taste and with bigger thickness, it is suitable for fresh consumption. It was determined in this research that the highest and lowest skin thickness values were measured for 'Kariz' and 'Derbigo' varieties, respectively. The 'Kariz' variety due to its highest $E$ $(=0.167 \mathrm{Mpa})$, has the most resilient and acts spring like against impacts and is less influenced by impacts. Therefore, in places with higher risk of external forces this variety can be more suitable for planting. Using punch test, it was signified that the external 'Falcato' stiffness was the lowest among the varieties at $\mathrm{P}<0.01$ ranged from 6.31-7.01 N.mm ${ }^{-1}$ and the stiffness of the other varieties did not have significant differences. The most average of stiffness was related to the green color ripeness ranged from $3.88 \mathrm{~N} . \mathrm{mm}^{-1}$ for internal bottom 
stiffness to $9.03 \mathrm{~N} . \mathrm{mm}^{-1}$ for external bottom stiffness and there was no significant difference between pink and red colors. After comparing the relations for estimating the $M$ and $V$, the regression models using three dimensions had the highest accuracy. The accurate models to determine the $V$ and $M$ were $(V=-191.834+1.877 T+1.396 W+1.944 L)$ with $\left(R^{2}=0.96, R S E=4.80\right)$ and $(M=-183.298+2.272 L+1.286 W+1.414 T)$ with $\left(R^{2}=0.96, R S E=4.44\right)$, respectively.

\section{Acknowledgement}

We would like to express our special thanks to the Shahrekord University for supplying the facilities in this research. Special thank is due to Fateme Noroozi for his assistance in editing the manuscript.

\section{References}

Anonymous. (2002). Retrieved from http://postharvest.tfrec.edu.

Anonymous. (2004). Retrieved from www.wagnerinstruments.com.

Baryeh, E. A., \& Mangope, B. K. (2002). Some physical properties of QP-38 variety pigeon pea. Journal of Food Engineering, 56, 59- 65. http://dx.doi.org/10.1016/S0260-8774(02)00148-6

Bourne, M. C. (1983). Guidelines for postharvest food loss reduction activities. United Nations Env. :Prog. Ind.

Carey, A. T., Holt, K., Picard, S., Wilde, R., Tucker, G. A., Bird, C. R., ... Seymour, G. B. (1995). Tomato Exo-(1-->4)-Beta-D-Galactanase: Isolation, changes during ripening in normal and mutant tomato fruit, and characterization of a related DNA clone. Plant Physiology, 108(3), 1099-1107. http://dx.doi.org/10.1104/pp.108.3.1099

Delina Felix, E., \& Mahendran, T. (2009). Phisico-chemical properties of mature green tomatoes (Lycopercicomesculentum) coated with pectin during storage and ripening. Tropical Agricultural Research and Extension, 12(2), 41-45.

Farahmand, M. (2008). Designing, manufacturing, and evaluation of an experimental model for saffron grading device. Tehran University: MS Dissertation.

Huber, D. J. (1985). A possible role for cellulose and cxcellulase actinity in locular get formation in tomato fruit. Scientia Horticulture, 20(3), 442- 443.

Kim, J., Gross, K. C., \& Solomos, T. (1991). Galactose metabolism and ethylene production during development and ripening of tomato fruit. Postharvest Biology and Technology, 1, 67-80. http://dx.doi.org/10.1016/0925-5214(91)90020-C

Mahmoodi, M., Khazaei, J., \& Vahdati, K. (2007). Discrimination of walnut genotypes using machine vision. $5^{\text {th }}$ National Congress of Agricultural Machinery Engineering, Mashhad (2007).

Mahmoodi, M. (2008). Modeling some mechanical property distribution of almond kernel using weibull function. $10^{\text {th }}$ International Congress of Mechanization and Energy in Agriculture, Antalya (2008).

Mahmoodi, M., Khazaei, J., \& Mohamadi, N. (2011). Modeling of geometric size distribution of almond. International Journal of Food Properties, 70, 310- 321.

Mazaheri Tehrani, M., Mortazavi, A., Shahidi, F., \& Nasiri Mahalati, M. (2003). Evaluating qualitative properties of tomato varieties. Agriculture and Natural resources sciences, 2, 39- 65.

Mazaheri Tehrani, M. (2007). Tomato production and processing. (4th ed.). Iran, Tehran: Marzdanesh Publication.

McGlone, V. A., \& Jordan, R. B. (2000). Kiwifruit and pricot firmness measurement: The non-contact laser airpuff method. Postharvest Biology and Technology, 19(1), 47-54. http://dx.doi.org/10.1016/S0925-5214(00)00068-5

McGlone, V. A., Jordan, R. B., Seelye, R., \& Martinsen, P. J. (2002). Comparing density and NIR methods for measurement of kiwifruit dry matter and soluble solids content. Postharvest Biology and Technology, 26, 191-198. http://dx.doi.org/10.1016/S0925-5214(02)00014-5

Mohsenin, N. N. (1986). Physical properties of plant and animal materials. New York: Gordon and Breach Science Publishers.

Nesvadba, P., Houska, M., Wolf, W., Gekas, V., Jarvis, D., \& Sadd, P. A. (2004). Database of physical properties of agro-food materials. Journal of Food Engineering, 61, 497-503. http://dx.doi.org/10.1016/S0260-8774(03)00213-9 
Ngouajio, M., Kirk, W., \& Goldy R. (2003). A simple model for rapid and nondestructive estimation of bell pepper fruit volume. Crop Horticulture Science, 38, 509-511.

Papadopoulou, P., \& Manolopoulou, H. (1990). The effect of air storage on fruit firmness and sensory quality of kiwifruit cultivars. Acta Horticulturae, 444, 607- 612.

Perez, E. E., Crapiste, G. H., \& Carelli, A. A. (2007). Some physical and morphological properties of wild sunflower seeds. Biosystem Engineering, 96, 41- 45. http://dx.doi.org/10.1016/j.biosystemseng.2006.09.004

Rafiee, S., Keramat Jahromi, M., Jafari Asharifi, M., Mirasheh, R., \& Mobli, H. (2007). Determining some physical properties of bergamot (citrus medica). International Agrophysics, 21, 293-297.

Rashidi, M., \& Seyfi, K. (2007). Classification of fruit shape in kiwifruit applying the analysis of outer dimensions. International Journal of Agricultural Biology, 5, 759-762.

Robbins, J. A., \& Moore, P. P. (1990). Fruit weight and strength in 'Meeker' red raspberry. Horticultural Science, 25, 679-681.

Sabliov, C. M., Boldor, D., Keener, K. M., \& Farkas, B. E. (2002). Image processing method to determine surface area and volume of axisymmetric agricultural products. International Journal of Food Properties, 5, 641-653. http://dx.doi.org/10.1081/JFP-120015498

Sadrnia, H., Rajabipour, A., Jafary, A., Javadi, A., \& Mostofi, Y. (2007). Classification and analysis of fruit shapes in long type watermelon using image processing. International Journal of Agricultural Biology, 1, 68-70.

Seymour, G. B., \& Gross, K. C. (1996). Cell wall disassembly and fruit softening. Postharvest News Info, 7 , 45-52.

Stroshine, R., \& Hamann, D. (1994). Physical properties of agricultural materials and food products. (2rd ed.). USA, West Lafayette: Purdue University.

Tabatabaeefar, A., Vefagh Nematolahee, A., \& Rajabipour, A. (2000). Modeling of orange based on dimensions. Journal of Agricultural Science and Technology, 2, 299-305.

Tabatabaeefar, A., \& Rajabipour, A. (2005). Modeling the mass of apples by geometrical attributes. Scientia Horticulture, 105, 373-382. http://dx.doi.org/10.1016/j.scienta.2005.01.030

Thakur, B., Singh, R., Tieman, D., \& Handa, A. (1996). Tomato product quality from transgenic fruits with reduced pectin methylesterase. Journal of Food Science, 61(1), 85-87. http://dx.doi.org/10.1111/j.1365-2621.1996.tb14731.x

Tianxia, W. U., Judith, L., \& Abbott, A. (2002). Firmness and force relaxation characteristics of tomatoes stored intact or as slices. Postharvest Biology and Technology, 24(1), 59-68. http://dx.doi.org/10.1016/S0925-5214(01)00133-8

White, A., Silva, H. N. D., Requejo Tapia, C., \& Harker, F. R. (2005). Evaluation softening characteristics of fruit from 14 species of actinidia. Postharvest Biology and Technology, 35(2), 143-151. http://dx.doi.org/10.1016/j.postharvbio.2004.08.004 